Journal of Animal and Veterinary Advances 11 (17): 3194-3197, 2012

ISSN: $1680-5593$

(C) Medwell Journals, 2012

\title{
Population Structure, Age and Growth of Sardine, Sardina pilchardus (Walbaum, 1792) in the Black Sea
}

\author{
Goktug Dalgic and Yusuf Ceylan \\ Faculty of Fisheries, Recep Tayyip Erdogan University, 53100 Rize, Turkey
}

\begin{abstract}
Population structure, age and growth of sardine from the Eastern Black sea coasts of Turkey were examined. A total of 684 Sardina pilchardus (Walbaum, 1792) were sampled between September 2009 and April 2010 from commercial purse-seine fleet operating along coasts of Rize. Total lengths of sardine were ranged between $11.0-17.9 \mathrm{~cm}$ and the weights ranged from $10.20-53.64 \mathrm{~g}$ regardless the sex. The sex ratio $(0 / \%)$ was found to be 1.14 in favor of males. In ageing, 3 classes (1-3 years) were determined from 86 sardine otoliths. Growth performance of sardine in the Black sea was lower than the other seas.
\end{abstract}

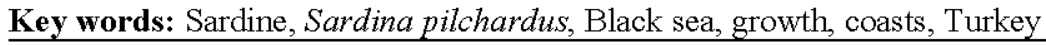

\section{INTRODUCTION}

The European sardine, Sardina pilchardus (Walbaum, 1792) is a well-known small pelagic inhabiting the Atlantic ocean along the coasts of Europe and Africa as well as the Mediterranean basin including the Black sea (Giannoulaki et al., 2011; Bilecenoglu et al., 2002; Reshetnikov et al., 2006). It is mainly fished by purse seiners and gill nets on the continental shelf of Turkey. According to the fisheries statistic data it was landed 27639 tons in 2010 and only a small proportion of this yield (1857 tons) captured from the Black sea (TUIK, 2012). Sustainable management of fisheries requires thorough knowledge of the population characteristics of each aquatic organism. Owing to this, many studies have targeted the biology (Cihangir and Tirasin, 1990; Cihangir, 1996; Karakayis and Togulga, 2000; Akalin et al., 2006; Gicili, 2007) length-weight relationships (Tarkan et al., 2006; Keskin and Gaygusuz, 2010) and genetics (Sarmasik et al., 2008) of sardine in Turkish seas. Nevertheless, biological information regarding the Black sea population is sparse. The objective of this study was to investigate the general population structure, age, growth and length-weight relationship of sardine from the Eastern Black sea coasts of Turkey.

\section{MATERIALS AND METHODS}

Monthly samplings of sardine were collected from commercial purse-seine fleet between September 2009 and April 2010 off Rize, South Eastern of the Black sea (Fig. 1). During the study, a total of 684 specimens were sampled. For each individual Total Length (TL) was measured to

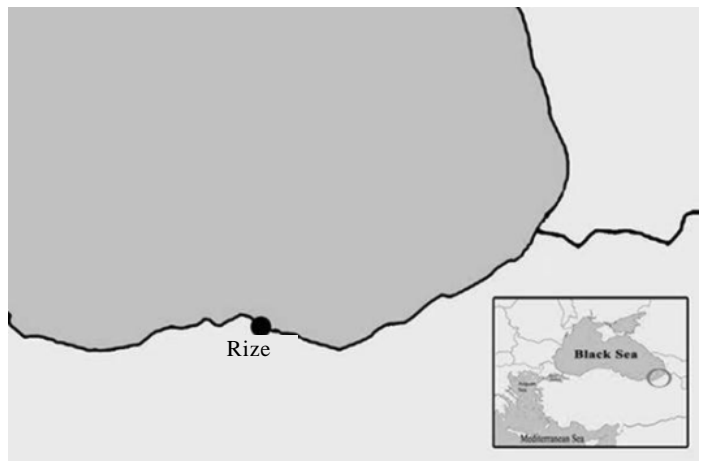

Fig. 1: Map illustrates sampling area (Rize) in the Black sea

the nearest millimeter with a digital Vernier caliper. The Weight (W) of each individual was determined on a top loading digital balance with a precision of $0.01 \mathrm{~g}$. The length-weight relationship was calculated applying the exponential regression equation $\mathrm{W}=\mathrm{aTL}^{\mathrm{b}}$ where $\mathrm{a}$ and $\mathrm{b}$ are the regression parameters (Ricker, 1975). After dissection of the bodies, gonads were examined in order to determine the sex. The sex ratio was controlled with $\chi^{2}$-test for any significant difference.

From each of $1 \mathrm{~cm}$ length class interval, at least 10 specimens were randomly chosen and the sagittal otoliths were removed. Age of the fish estimated from 86 otoliths by 2 readers with the help of stereoscopic microscope. The first of January adopted as the birth date reference for age assignment purposes (Soares et al., 2005). In order to estimate the age-length relationship the Von Bertalanffy growth function was used (Ricker, 1975):

$$
L_{t}=L_{\infty}\left(1-e^{-K\left(t-t_{0}\right)}\right)
$$


Where:

$\mathrm{L}_{\mathrm{t}} \quad=$ Length at age $\mathrm{t}(\mathrm{cm})$

$\mathrm{L}_{\infty} \quad=$ Theoretical maximum length $(\mathrm{cm})$

$\mathrm{K}=$ Von Bertalanffy growth constant

$\mathrm{t}_{0}$ (years) $=$ Theoretical length at age zero

Growth performance of sardine was estimated using the index of $\Phi^{\prime}=\log \mathrm{K}+2 \log \mathrm{L}_{\infty}$ (Pauly and Munro, 1984).

\section{RESULTS AND DISCUSSION}

Of all examined S. pilchardus, 319 (46.64\%) specimens were female and $365(53.36 \%)$ were male. Overall sex ratio ( $\left.\sigma^{1 / \%}=1.14\right)$ was not differed significantly from 1:1 $\left(\chi^{2}=3.094, p=0.549\right)$. Total lengths and weights of males ranged between 11-17.2 (14.45 \pm 1.21$) \mathrm{cm}$, 10.2-53.64 (23.82 \pm 6.24$) \mathrm{g}$, respectively. For females, total lengths and weights ranged between 11.4-17.9 $(14.68 \pm 1.30) \mathrm{cm}$ and $11.29-47.61$ (25.18 \pm 7.34$) \mathrm{g}$, respectively. There were statistically significant differences between both lengths (Mann-Whitney U test $=51606, \mathrm{p}=0.010$ ) and weights (Mann-Whitney $\mathrm{U}$ test $=52079, \mathrm{p}=0.017$ ) of females and males. The length-frequency distribution of $S$. philchardus sampled in the study is given in Fig. 2.

The relationship of total length and weight parameters of specimens were exponential. Positive allometric growth was present between length-weight variables of females while it was isometric in males (Fig. 3). There was significant differences in terms of allometric coefficient between females and males ( $p=0.003$; $\mathrm{F}=9.040$ ). The Von Bertalanffy growth curve parameters; Asymptotic Length $\left(\mathrm{L}_{\infty}\right)$, growth coefficient $(\mathrm{K})$, theoretical length at age zero $\left(\mathrm{t}_{0}\right)$ and age-ranges of the specimens are shown in Table 1. There were significant differences in terms of growth parameters for both sex $(p<0.05)$. Calculated growth performance values $\left(\Phi^{\prime}\right)$ indicated that males had higher growth rates than females.

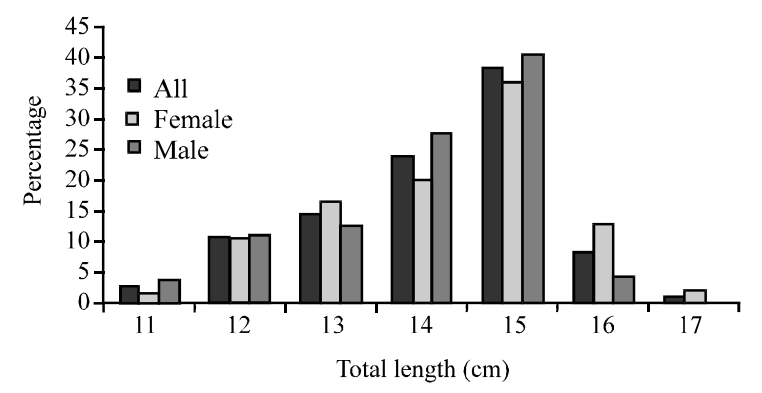

Fig. 2: The length-frequency of Sardina pilchardus off the Black sea
In the present study, sex ratio of $S$. philcardus in the Black sea was not significantly differ from 1:1. Probably, due to environmental differences between the sampling areas, sex ratio was skewed towards females in the Adriatic (Pesic et al., 2010; Sinovcic et al., 2008) and in the North Aegean sea (Cihangir, 1996; Gicili, 2007; Tekinay et al., 2002). In general, greater numbers of females in the fish schools indicate greater rates of reproduction (Wootton, 1982). Mean lengths and weights of $S$. philcardus reported in this study are in accordance with the studies conducted in different seas of Turkey (Cihangir, 1991; Gicili, 2007; Sarmasik et al., 2008). Larger sardine lengths (Atlanto-Iberian stock area with a mean length of $22.1 \mathrm{~cm}$ in Asturias, $20.3 \mathrm{~cm}$ in Algarve (South Portugal) and $22.0 \mathrm{~cm}$ off Northwestern France) were reported from the Western Mediterranean and Atlantic populations (Silva, 2003). After measuring 51,246 individuals, Voulgaridou and Stergiou (2003) calculated mean length of $14.48(8-21) \mathrm{cm}$ for the Northwest Aegean Sea sardine.

In terms of the relationships between the weight and dimensional parameters, calculated from regression and correlation analyses, the growth was determined to be allometric for females and isometric for males. Both

Table 1: Sardina philcardus length at age, $\mathrm{L}_{+\infty}, \mathrm{K}, \mathrm{t}_{0}$ and $\Phi$ values obtained off the Black sea

\begin{tabular}{llcccccc}
\hline Sex & L1 (n) & L2 (n) & L3 (n) & L $_{\text {ra }}$ & K & $\mathrm{t}_{0}$ & $\Phi^{\prime}$ \\
\hline Female & $12.7(6)$ & $14.78(32)$ & $16.43(8)$ & 23.61 & 0.209 & -2.749 & 2.066 \\
Male & $12.9(18)$ & $14.54(15)$ & $15.45(7)$ & 16.54 & 0.607 & -1.482 & 2.221 \\
All & $12.87(24)$ & $14.75(47)$ & $16.1(15)$ & 19.57 & 0.329 & -2.257 & 2.100 \\
\hline
\end{tabular}
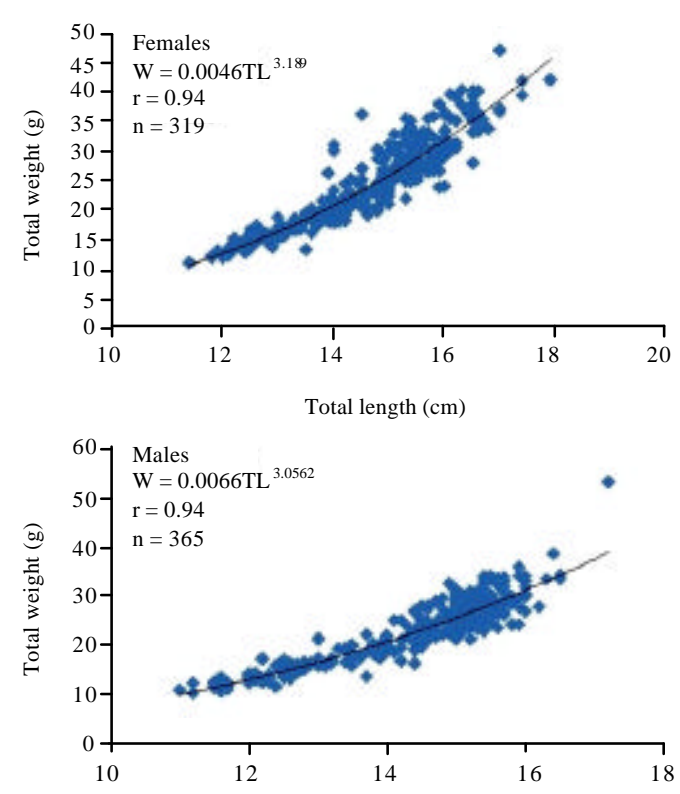

Fig. 3: Length-weight relationships of female and male Sardina philcardus in the Black sea 
negative and positive allometric growths were announced in Dardanelles $(b=2.68)$ in Northeast Aegean Sea $(b=$ 2.652) in East Aegean sea $(b=3.103)$ and in the Sea of Marmara ( $b=3.54$ ) for sardines (Cihangir, 1991; Gicili, 2007; Tarkan et al., 2006; Tekinay et al., 2002). Food availability, water temperature of the sampling locations and differences in maturity stages may be the reasons of these significant differences (Weatherley and Gill, 1987). S. philcardus is a short-lived pelagic species in which maximum age generally up to 7 years in the Aegean sea (Torcu, 1987). Mean lengths at first age fluctuated year by year between 9.81 and $12.11 \mathrm{~cm}$ in the Aegean sea and fishes were attained maximum $14.86 \mathrm{~cm}$ mean length at the end of 3rd year (Gicili, 2007; Cihangir, 1991). In this study oldest age estimated for $S$. philcardus was differed from other studies. Environmental conditions and fishing pressure may be the cause of this difference.

In order to compare different populations of the same species, the growth performance index $\left(\Phi^{\prime}\right)$ gives valuable data (Sparre et al., 1987). According to the $\Phi^{\prime}$ values males grew faster than females in the Black sea. Similar results were reported for the males in the Aegean sea (Akyol et al., 1996). Results were indicated that $S$. philcardus population grew slower in the Black sea than the populations inhabiting other seas (Gicili, 2007; Alemany and Alvarez, 1993).

\section{CONCLUSION}

According to Fishbase spawning period of $S$. philcardus occurs between June and August in the Black sea (Banarescu, 1964). Recently sardine larvae were sampled during an egg-larvae survey in a very close area to the sampling station in July (Ak, 2012). Nevertheless nonexistence of $0+$ age class in this study showed that further researches are required in order to prove if the spawning occurs or not along the Black sea coasts.

\section{REFERENCES}

$\mathrm{Ak}, \mathrm{O} ., 2012$. Horse mackerel from egg to adult off trabzon coasts (Trachurus mediterraneus, Steindachner, 1868): Age, growth, mortality and reproduction. Interim Report of TAGEM/HAYSUD/2011/09/02/07: Group Meeting of Ministry of Food, Agriculture and Livestock, pp: 11.

Akalin S., O. Ozaydin, D. Uckun and M Togulga, 2006. A preliminary study on the daily growth of European sardine (Sardina pilchardus Walbaum, 1792) in Izmir Bay. J. Fish. Aquatic Sci., 23: 357-360.
Akyol, O., A. Tokac and S. Unsal, 1996. An investigation on the growth and reproduction characteristics of the sardine (ardine pilchardus Walbaum, 1792) in the Bay of Izmir (Aegean Sea). E.U. Su Urunleri Dergisi, 13: 383-394.

Alemany, F. and F. Alvarez, 1993. Growth differences among sardine (Sardina pilchardus Walb.) populations in Western Mediterranean. Scientia Mar., 57: 229-234.

Banarescu, P., 1964. Pisces-Osteichthyes (Pesti Ganoizi si Ososi). Fauna Republicii Populare Romine Vol. 13, Academiei Republicii Populare, Bucharest, Romine, pp: 223-251.

Bilecenoglu, M., E. Taskavak, S. Mater and M. Kaya, 2002. Checklist of the marine fishes of Turkey. Zootaxa, 113: 1-194.

Cihangir, B. and E.M. Tirasin, 1990. Investigations on the gonadosomatic index and condition factor of Aegean Sea sardine (Sardina pilchardus Walbaum, 1792). X. Ulusal Biyoloji Kongresi, pp: 233-242.

Cihangir, B., 1991. The reproductiative biology and growth of the Pilchard ( Walbaum, 1792) in Aegean Sea. Ph.D. Thesis, Department of Marine Biology Technology, Dokuz Eylul University, Izmir, Turkey.

Cihangir, B., 1996. Reproduction of european pilchard, Sardina pilchardus (Walbaum, 1792) in the Aegean Sea. Turk. J. Zool., 20: 33-50.

Giannoulaki, M., M.M. Pyrounaki, B. Liorzou, I. Leonori and V.D. Valavanis et al., 2011. Habitat suitability modelling for sardine juveniles (Sardina pilchardus) in the Mediterranean Sea. Fish. Oceanogr., 20: $367-382$.

Gicili, S., 2007. Investigation on the biological aspects of the European Pilchard (Sardina pilchardus Walbaum, 1792) in Edremit Bay, Aegean Sea. Master Thesis, Institute of Science, Department of Biology, Balikesir, Turkey.

Karakayis, M. and M. Togulga, 2000. Study on the biology of the sardine (Sardina pilchardus Walbaum, 1792) in the Izmir Bay (Aegean Sea). Ege Univ. Urunleri Dergisi, 17: 59-69.

Keskin, C. and O. Gaygusuz, 2010. Length-weight relationships of fishes in shallow waters of Erdek bay (Sea of Marmara, Turkey). IUFS J. Biol., 69: 25-32.

Pauly, D. and J.L. Munro, 1984. Once more on the comparison of growth in fish and invertebrates. Fishbyte, 2: 21-21.

Pesic, A., M. Durovic, A. Joksimovic, S. Regner, P. Simonovic and B. Glamuzina, 2010. Some reproductive patterns of the sardine, Sardina pilchardus (Walb, 1792), in Boka Kotorska Bay (Montenegro, southern Adriatic Sea). Acta Adriatica, 51: $85-92$. 
Reshetnikov, S.I., A.N. Pashkov and B.K. Bondarev, 2006. A new case of catching the European pilchard Sardina pilchardus (Clupeidae, Clupeiformes) in the Northeastern part of the Black Sea. J. Ichtyol., 46: 803-805.

Ricker, W.E., 1975. Computation and interpretation of biological statistics of fish populations. Bull. Fish. Res. Board Can., 191: 1-382.

Sarmasik, A., F.A. Colakoglu and T. Altun, 2008. Mitochonrial DNA sequence variations in sardine (Sardina pilchardus) stocks of Turkey. Turk J. Zool., 32: 229-237.

Silva, A., 2003. Morphometric variation among sardine (Sardina pilchardus) populations from the northeastern Atlantic and the western Mediterranean. ICES J. Mar. Sci., 60: 1352-1360.

Sinovcic, G., V.C. Kec and B. Zorica, 2008. Population structure, size at maturity and condition of sardine, Sardina pilchardus (Walb., 1792), in the nursery ground of the eastern Adriatic Sea (Krka River Estuary, Croatia). Estuar. Coastal Shelf Sci., 76: 739-744.

Soares, E., A. Silva and A. Morais, 2005. Report of the workshop on sardine otolith age reading and biology. National Institute of Agricultural Research and Fisheries, IPIMA, Lisbon, Portugal. http://www.ices. $\mathrm{dk} /$ reports/acfm/pgccdbs/pil.agewk2005.pdf.

Sparre, P., E. Ursin and S.C. Venema, 1987. Introduction to tropical fish stock assessment. Part 1: Manual, FAO Fisheries Technical Paper, Roma, Italy.
TUIK, 2012. Turkish fisheries statistics. Turkish Statistical Institute, Turkey. http://www.tuik.gov.tr/VeriBilgi. do?tb_id=47\&ust_id=13.

Tarkan, A.S., O. Gaygusuz, H. Acipinar, C. Gursoy and M. Ozulug, 2006. Length weight relationship of fishes from the Marmara Region (NW-Turkey). J. Applied Ichthyol., 22: 271-273.

Tekinay, A.A., P. Akyuz, D. Guroy, E.G. Kahyaoglu and M. Alpaslan, 2002. An investigation on some population parameters of European pilchard (Sardina pilchardus Walbaum 1792) in the Dardanelles. Turk. J. Mar. Sci., 8: 131-139.

Torcu, H., 1987. Biological and ecological investigation on Sardina (Sardina pilchardus Walbaum, 1792) Population in the Izmir bay. Master Thesis, Department of Marine Biology Technology, Dokuz Eylul University, Izmir, Turkey.

Voulgaridou, P. and K.I. Stergiou, 2003. Trends in various biological parameters of the European sardine, Sardina pilchardus (Walbaum, 1792), in the eastern Mediterranean Sea. Scientia Marina, 67: 269-280.

Weatherley, A.H. and H.S. Gill, 1987. The Biology of Fish Growth. Academic Press, London, Pages: 443.

Wootton, R.J., 1982. Environmental Factors in Fish Reproduction. In: Reproductive Physiology of Fish, Richter, C.J.J. and H.J.T. Goos, (Eds.). Pudoc, Wageningen, The Netherlands, pp: 210-219. 